\title{
Sanatsal Yaratım Ekseninde Bir Olanak: Tekstil Malzemeleri Takviyeli Kâğıt Yapılar*
}

\author{
A Possibility for Artistic Creation: Paper Structures Reinforced with Textile Materials \\ Esra Dereli, Geleneksel Türk Sanatları Bölümü, Sinop Üniversitesi \\ Özlenen Erdem İșmal, Tekstil ve Moda Tasarımı Bölümü, Dokuz Eylül Üniversitesi
}

\begin{abstract}
Özet
Kâğıt, başta kitap sanatları olmak üzere, sanatın hemen hemen tüm kollarında kullanılmaktadır. Fakat görülen odur ki; bu malzeme daha çok üzerinde çizgi, şekil, renk veya motif bulunan, bir ifadeyi ya da duyguyu ileten araç olarak kullanılmıştır. Kâğıdın kendisi sanatsal bir söylem olarak ele alındığında ise, bu çerçevenin daraldığı görülmektedir.

Malzemeyi tasarlamak amaçlandığında; kağıdın içeriğine odaklanarak üretim aşamasından itibaren olanakları değerlendirme gereği duyulmuştur. Böylelikle, sanatsal ifade yöntemlerinin genişletebileceğini söylemek mümkündür. Bu noktadan hareketle ve çevreci bir hassasiyetle; ikincil liflerden oluşan kâğıt hamurunda, geri dönüșümden elde edilen tekstil liflerinin ve atıklarının kullanıldığı kompozit bir yapı oluşturulmuștur.

Geleneksel malzemelerden farklı olarak, yenilikçi bir yaklaşımla deneysel bir çalışma yapılmıştır. Bu şekilde elde edilen reçete, kompozit üretim yöntemiyle birleștirilmiș ve kâğıdın biçimsel olarak da yorumu deneyimlenmiştir. Sanatsal söylem, bu yeni malzemenin ve kompozit üretimin sunduğu olanaklarla birleștirilerek Tılsımlı Gömlek formunda bir tasarıma dönüștürülmüştür. Tılsımlı gömleklerin özel işleme tabi tutularak kâğıt vasfi kazandırılmış kumaşlardan dikildiği bilinmektedir. Bu kumaşların özelliklerinden esinlenerek de, tekstil malzemeleri takviyeli kâğıt yapılar (kompozitler) oluşturulmuştur. Bu sayede özgün bir yaratım malzemesi olarak üretilen kompozitler, tezyinî sanatlarla bağdaștırılmıs kavramsal bazı çıkarımlar içeren bir tasarımla sanatsal söyleme dönüștürülmüștür.
\end{abstract}

Anahtar Sözcükler: Kâğıt hamuru, tılsımlı gömlek, tasarım, kompozit, tekstil lifleri, geri dönüşüm, atık.

Akademik disipin(ler)/alan(lar): Sanat ve tasarım.

\begin{abstract}
Paper is a material that is used in nearly every branch of art, especially book arts. However, it is clearly seen that paper is mainly used as a material which transfers an expression or a feeling with its lines, shapes, colours or patterns. When paper itself is considered as an artistic expression, this framework seems to have narrowed.
\end{abstract}

When the purpose is to design the material; it is necessary to evaluate the possibilities starting from the production stage by focusing on content of the paper. In this way, it is possible to suggest that the artistic expression methods can be expanded. From this point of view and with an environmental sensitivity, a composite structure is formed for secondary fiber paper pulp using waste textiles and recycled fibers.

As an alternative to conventional materials, an experimental study has been conducted with an innovative approach. The approach obtained in this way has been combined with the composite production method and the interpretation of the paper as a form was experienced. Artistic expression was transformed into a design in the form of talismanic shirt by combining the possibilities of this new material and composite production. It is known that these shirts are stitched from fabrics that have been imparted with paper characteristics by special process. Inspired by the properties of these fabrics, paper structures reinforced with textile materials (composites) were created. In this way, the composites, -which are produced as original creative material- have been transformed into artistic expression with a design which includes certain conceptual references associated with art of ornamentation.

Keywords: Paper pulp, talismanic shirt, design, composite, textile fibers, recycling, waste.

Academical disciplines/fields: Art and design.

\footnotetext{
* Bu çalışma, Tekstil ve Kâğıt Yapılı Kompozit Uygulamalar ve Sanatsal Çalışmalar adlı yüksek lisans tezinden türetilmiştir.
}

- Sorumlu Yazar: Esra Dereli, Geleneksel Türk Sanatları Bölümü, Güzel Sanatlar Fakültesi, Sinop Üniversitesi

- Adres: Osmaniye Köyü Nasuhbaşoğlu Mevkii 57000, Sinop.

- $\quad$ e-posta: edereli@sinop.edu.tr

- ORCID: 0000-0001-8942-3613

- Çevrimiçi yayın tarihi: 15.07 .2020

- doi: $10.17484 /$ yedi.685078 


\section{Giriș}

İnsanlığın en önemli ihtiyaç malzemelerinden biri olan kâğıdın keşfinden önce de, onun yerini tutabilecek tablet, levha, ağaç kabukları ve hayvan derileri gibi malzemeler kullanıldığı görülmüştür. Bu çerçeveden bakıldığında insanın doğası gereği bilgisini, deneyimini, gözlemini ve duygusal dışavurumlarını, gerek yazı gerekse de çizgi, şekil veya form olarak aktarma ihtiyacı hissettiğini söylemek mümkündür.

Günümüze gelindiğinde ise kâğıt, kullanım alanı paradan mendile, ambalajdan mobilyaya kadar oldukça geniş bir yelpazeye sahiptir. Kâğıt, kullanım alanındaki bu çeşitlilik göz önünde bulundurulacak olduğunda, yapısı gereği birbirinden bağımsız gibi görülebilecek pek çok çalışma alanını bünyesinde barındıran ve sanat, tasarım, mühendislik, teknoloji, moda vs. gibi pek çok disiplin içerisinde farklı perspektiflerden ele alınan bir yapıya sahiptir. Bu anlamda ülkemizde yapılmış çalışmalar incelendiğinde, konunun daha çok orman, endüstri mühendisliği ve kimya mühendisliği kapsamında olduğu görülmüştür. Güzel Sanatlar alanında yapılan çalışmalar araştırıldığında ise kâğıdın ağırlıklı olarak, taşıyıcı yüzey niteliğinde kullanılan bir malzeme olduğu ya da restorasyon çalışmalarına kaynaklık ettiği göze çarpmaktadır. Bunların dışında kalan çalışmalarınsa daha çok endüstriyel kâğıdın kullanıldığı ve kıvırma (quilling-kâğıt telkâri), katlama (origami), oyma (kat'ı) ya da kesme (krigami) gibi yöntemlerle kâğıdın şekillendirilmesine yönelik olduğu görülmüștür.

Kullanım sahasındaki çeşitlilik, kâğıdın üretimiyle ilgili olarak çeşitli alternatiflere yol açmış olmasına rağmen, endüstriyel kâğıtların sanatsal söylemi olan bir tasarıma dönüştürülmek istendiğinde sanatçının ifade olanaklarına yeterli gelmediği gözlenmiştir. Bu çalışmada olduğu gibi, kâğıdı sanayileşmiş hali ve standart özellikleri dışında kullanmak isteyenlerin taleplerini karşılayacak nitelikte; ABD'de 43, Japonya'da 10, Avustralya ve Kanada'da 5, Almanya'da 4, Avusturya ve İsrail'de 3, İngiltere'de 2, Arjantin, Bahamalar, Filipinler, Finlandiya, Fransa, Hindistan, İspanya, İsveç, İsviçre, İtalya, Nepal, Tanzanya ve Yeni Zelanda'da ise birer adet el yapımı kâğıt üretimi yapan kuruluș bulunmaktadır (Güven, Kaplanoğlu ve Yangöz, 2012, s. 55-57).

Endüstriyel alanda olduğu gibi, sanatsal çerçevede biçimlendirilecek olduğunda da, kâğıdın teknik ve mühendislikten bağımsız olmadığı gözlenmiş; kâğıdın kendisi tasarlanmak istediğinde; malzemeyi tanımak, elde üretim yöntemlerini bilmek ve üzerinde alternatifler geliştirmek durumunda kalınmaktadır. Örneğin kâğıtla ilgilenen pek çok sanatçı ve tasarımcı tarafından bilinen ve hanji olarak adlandırılan bir kâğıt çeşidi, sahip olduğu birbirinden farklı özellikle pek çok alanda çalışma konusu olmuştur. Bu kâğıdın sanat alanında olduğu kadar; tekstil, moda ve endüstriyel tasarım alanlarındaki varlı̆̆ı, pencere, kapı, duvar kâğıdı, kaplama malzemesi ve titreşim paneli olarak kullanılması, ancak malzemenin bünyesinde barındırdığı özellik ve sunduğu olanakların keşfiyle mümkün olmuştur. Aynı durumun kâğıdı kendine malzeme olarak seçmiş sanatçı için de geçerli olduğu görülmektedir. Malzemeyi tanımanın, onunla yapılabileceklerin sınırlarını genişletecek en iyi referans olmakla birlikte, ilgi alanlarına göre çeşitli açılımlar yapılmasını sağladığı söylenebilir. Çünkü böylelikle amaç elde kâğıt üretmekten ziyade, bu yöntemi çeşitli alternatiflerle buluşturarak, ifade olanaklarını genişletmek olacaktır.

Bilindiği üzere icadından beri kâğıt üretimi için su kaynakları olmazsa olmaz şartların başında yer almış ve ağaçlar birincil lif kaynakları olarak kullanılmıştır. Söz konusu kâğıt olduğunda bahsedilen bu iki unsur, çevreci kaygılar gütmek için son derece önemli ve yeterli sebeplerdendir. Dolayısıyla bu çalışmada, birincil kaynaklarından elde edilen prosese kıyasla üretimi çok daha zor olan malzeme kaynağını, ikincil kaynaklar olan atıklar oluşturmaktadır. Aynı zamanda bir kompozit yapı olarak da kabul edilen kâğıdın elde yapım tekniğiyle; geri dönüştürülmüş lif kaynakları ve tekstil atıkları, atık kâğıt hamuruyla birleştirilmiş ve ortaya kompozit bir yapı çıkarılmıştır. Kompozit yapıların mantığında, bünyesindeki bileşenlerden herhangi birinin tek başınayken sahip olmadığı özelliği, farklı sistemlerin buluşturulması yoluyla ona kazandırmak vardır. Zayıflayan lif yapısıyla atık ve geridönüșüm malzemelerinin kaynaklık ettiği düşük vasıflı bu kâğıt yapı, kompozit üretim yoluyla nitelikli hale getirilmiştir.

Özellikle son yıllarda atıkların, sanatçıların kendileri için seçtikleri malzemeler sınıfına girdiği görülmektedir. Alternatif malzemeler, sanatçının simyası, yaratıcı eylemleri ve özgün yorumlarıyla birer sanatsal yapıta dönüşmektedir. Böylelikle hem atık konusunda bir farkındalık oluşturulmakta, hem de nesne üzerinden sanatsal söylem gerçekleştirilmektedir. Konu bu anlamda değerlendirilecek olduğunda Marcel Duchamp'ın 1917'de yaptığı Çeşme örneğinde olduğu gibi sanat dışı nesneler de, o nesnenin felsefî bir değerlendirmesiyle birlikte sanat başlığı altında kendine yer edinebilmektedir. Bahsi geçen bu görüşün yanı sıra Heideger'e göre de malzeme, sanatsal biçimlendirmenin alanını sağlar ve fakat "malzeme ve biçim hiçbir zaman salt nesnenin nesnelliğinin temel belirlenimi değildir." (Heideger, 2007, s. 21, 22) 
Çalışmanın çıkış noktasını oluşturan alternatif malzeme ve yöntem arayışı, kâğıdın elde üretim yoluyla sunduğu deneysel özgürlükle birleştirilmiş ve bu arayıșta her ne kadar atıktan elde edilen kâğıt hamuru kompozit üretim yoluyla kuvvetlendirilmeye çalıșılmıșsa da, sanayileșmiș kâğıtta hata gibi görülebilecek unsurlar önemsenmeksizin, sanat aracılığıyla yorumlanmak istenen kavramsal bazı söylemlerin Tılsımlı Gömlek formunda tasarlanması amaçlanmıştır. Osmanlı'da bir gelenek olarak bilinen bu gömlekler; daha çok koruyan, şifalandıran ya da uğur veren giysiler olarak geçmişten günümüze kalmış kültür miraslarıdır. Tılsımlı Gömlekler, üzerine yazılan çeşitli ayet, dua ve sembolik anlamlarla kazandıkları işlevselliklerinin yanı sıra, tezyinatıyla da dikkat çeken estetik gösterişe sahip tekstillerdir. Ancak bahsi geçen tüm özelliklerinin yanı sıra Tılsımlı Gömlekler, bu çalışmanın da ilham kaynaklarından biri olduğu üzere kumaş özellikleriyle oldukça dikkat çekicidir. Giyilebilen bir tekstil olmasına rağmen kitap sanatlarında özellikle hattatların kullandığı bir yöntem olan âharlama işlemiyle yüzeyinin kâğıt gibi kullanılarak yazı ve tezyinata elverişli hale getirilmesi, kâğıt özelinde malzemeye yaklaşım bağlamında bu çalışma için pencere açmış ve reçete hazırlamaya yönlendirdiği gibi, yüzeyindeki bezeme anlayış unsurları ve özgün formuyla da sanatsal uygulamada yer almıştır.

\subsection{Kâğıt Üretimi}

Günümüz kâğıdına en çok benzeyen malzemenin M.Ö. 105 yılında Çin Hanedanlığından Tsai Lun tarafından üretildiği kabul edilmektedir. Tsai Lun, dut ağacının dış tabakasını, özellikle böğürtlen liflerini ve buna benzer çalıların dallarını sıcak suda kaynatıp döverek lifli bir kütle elde etmiştir (Varlıbaş, 2010, s. 1). Lun, bol su içerisinde dağıttı̆̆ı bu lifli kütleyi, kabaca dokunmuș kumașın gerdirilmesiyle olușturulan bir süzme kasnağı üzerine dökerek, ilk kâğıdı elde etmiştir. Bazı kaynaklarda bunlara ek olarak hurda balıkçı ağlarının ve pamuklu eski bezlerin kullanıldığı da geçmektedir (Güven vd., 2012, s. 49).

Aslında günümüz kâğıt üretim tekniği de temel yapı itibariyle bu aşamalardan çok farklı değildir. Öncelikle bireysel liflerden oluşan kâğıt hamuru üretilmektedir. Oldukça seyreltik bir süspansiyon halinde hazırlanan hamur, ince eleği olan kalıplarda süzülerek kâğıt taslağı elde edilmektedir. Yaş haldeki bu taslak kademeli olarak preslenip kurutulmakta ve sonuç olarak kâğıt elde edilmektedir. Kısacası Tsai Lun'un kullandığı yöntemin, Şekil 1'de görülebileceği gibi, bir anlamda en ilkel termo mekanik kâğıt hamuru üretimi olduğunu söylemek mümkündür (Varlıbaş, 2010, s. 1).

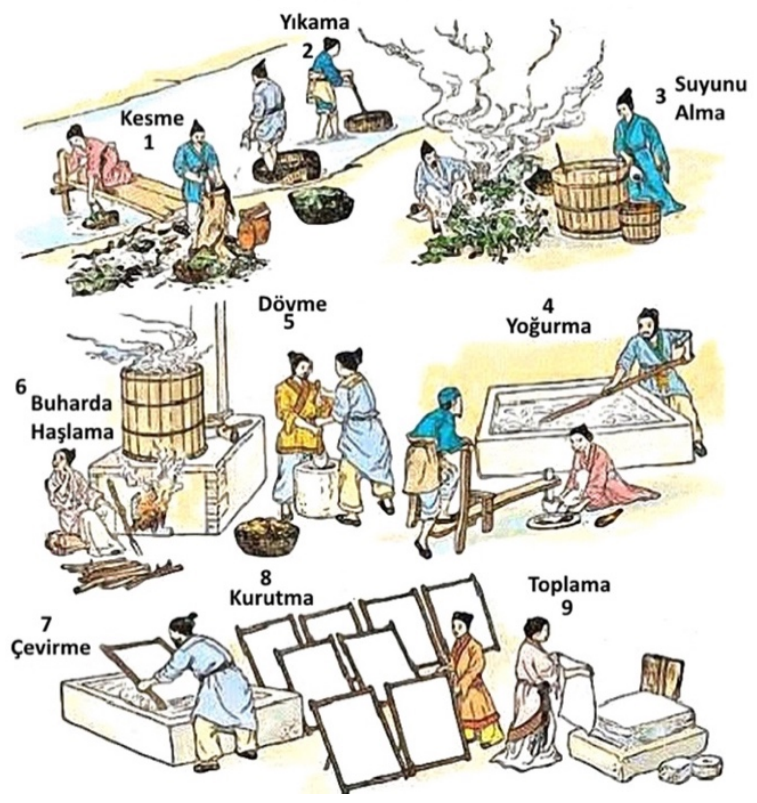

Şekil 1. Kâğıt yapım aşamaları (Yalçın, 2017).

Kısaca tanımlanacak olduğunda kâğıt; "bitkisel selülozun mekanik veya kimyasal yollarla liflendirilmesiyle veya kullanılmış kâğıtların yeniden liflendirilmesi ile elde edilen hamurlardan üretilen, üzerine baskı yapmaya elverişli tabaka" (Yakut, 2012, s. 68) ya da geleneksel olarak, sulandırılmış hamur halindeki liflerin ince bir süzgeç üzerinde oluşturduğu keçe levha, olarak ifade edilebilir (Karahan, 2008, s. 2). Dolayısıyla kâğıt hamuru için de, "...bireysel hale getirilmiş selülozik lif kümeleri" (Kömbeci, 2014, s. 14) tanımını yapmak mümkündür. 
Kâğıtçılıkta lignoselülozik bir hammaddeden elde edilen ve ilk defa kâğıt yapımında kullanılacak olan lifler primer lifler (virgin fibres, birincil lif), atık kâğıtların işlenmesi ile elde edilen lifler ise sekonder lifler (ikincil lif) olarak tanımlanmaktadır (Karahan, 2008, s. 4). Ancak ikincil lif sınıfına giren atık kâğıttan yeniden kâğıt üretiminde, işlem basamaklarında bazı sorunlar yaşanmaktadır. Bu sorunları en aza indirgemek amacıyla; atık kâğıtları orijinal derecelerine göre sınıflandırarak toplamak, geri dönüşümlü kâğıt üretiminin ilk ve önemli bir aşamasıdır (Selimbeyoğlu, 2001, s. 47). Benzer türdeki kâğıtlarla yapılmış geri dönüşüm işlemi; geri kazanılan selüloz liflerinin kalitesini yükselttiği gibi, prosesin verimini de olumlu yönde etkilemektedir (Erentürk, 2014, s. 12). Kullanılmış kâğıtlar temel olarak karışık atıklar, oluklu ambalaj atıkları, eski gazete kâğıtları, selüloz alternatifi atıklar ve yüksek vasıflı matbua atıklar olarak sınıflandırılabilir (Yakut, 2012, s. 70).

Geri dönüştürülmüş kâğıtlar farklı özelliklere sahiptirler. Bu kâğıtların doğasında ve kalitesinde; kullanılan atık kâğıdın cinsi, ham selüloz kullanılmışsa bunun geri dönüşümlü kâğıtla karışma oranı, temizleme ve üretim aşamalarındaki detayların hepsi birden etkilidir (Selimbeyoğlu, 2001, s. 9). Geri dönüşümün genellikle lifler, dolayısıyla da kâğıt üzerinde istenmeyen etkileri bulunmakta, selülozun yapısında değişimler meydana gelmektedir. Bu duruma örnek olarak; geri dönüşüm esnasında liflerin şişme yeteneğinin kaybolması ve esnekliğinin azalması, mürekkep, yapışkan gibi var olan kirleticilerin liflerle birleşmesi gösterilebilir (Bozkurt, 2012, s. 8).

Geri dönüştürülmüş kâğıdın fiziksel ve optik özelliklerini iyileștirmek adına yapılan çalışmalardan bazı çıkarımlar yapılmakla birlikte, elde edilen verilerin kâğıt hamurunda kullanılan lif özelliklerine bağlı olarak değişkenlik gösterebildiği sonucuna ulaşılmıştır. Bahsi geçen duruma örnek olarak; geri dönüşümden kâğıt yapım aşamasında, liflerin yeniden şişme ve bağ yapma özelliğini kaybetmesi nedeniyle dövme gibi yoğun bir işlemin liflerin özelliklerini yeniden kazandırmak için gerekli olduğu görülmüş, ancak dövmenin etkisinin hamur türüne de bağlı olduğu gözlenmiştir. Bunun yanı sıra, dövme işlemi doğru yapılmadığı takdirde de, lif uzunluğunda kısalma ve yırtılma direncinde azalma meydana gelir. Bu işlem çoğu zaman üretim kapasitesi ve drenajın azalmasına sebebiyet verdiğinden yeniden kâğıt hamuru üretiminde direnç özelliklerini geliştirmek için dövme işlemine alternatif olarak kimyasal katkı maddeleri kullanımı da mevcuttur. Örneğin, üretimde kullanılan katkı maddeleri ve üretim yardımcılarından olan şap ve yapıştırma kimyasallarının, geri dönüşüm potansiyelini beklenenin ötesinde azalttı̆̆ı ifade edilirken (Erentürk, 2014, s. 24, 26); bazı araştırmacılar da atık kâğıtların geri dönüşümünden elde edilen selüloz liflerinin yeniden kâğıt imalinde kullanılması esnasında kâğıt hamuruna belirli oranlarda CMC (Karboksi Metil Selüloz), nişasta ve şap katılmasının, kâğıda fiziksel ve optik özelliklerde artış meydana getirdiğini ve aynı liflerin geri dönüşüm sayısını artırdığını açıklamışlardır (Bozkurt, 2012, s. 7). Kimyasal bir yöntem olarak liflerin soda ile muamele gördüğü uygulamalar da bulunmaktadır. Atık kâğıdın sodyum hidroksit ile muamelesi, geri dönüştürülmüş liflerin direnç özelliklerini ve serbestlik derecelerini arttıran bir yöntemdir. Ancak bahsi geçen tüm bu tespit ve gözlemler yukarıda da ifade edildiği gibi, kâğıt hamuruna ve bunun için kullanılan lif özelliklerine bağlı olarak değişkenlik gösterebilmektedir (Erentürk, 2014, s. 21,27).

\subsection{Kompozit Malzemeler}

Kompozitler; bir ara yüzey ile ayrılmış olan, kimyasal ve fiziksel olarak en az iki farklı fazdan oluşan malzemeler olarak tanımlanabilirler (Jose vd. 2012, s.3). İnsan yapısı bir kompozit tipik olarak; sürekli matris fazına yerleştirilmiş olan katı, sağlam, doğası itibarıyla da çoğunlukla lifli yapıdaki takviye fazından oluşmaktadır (Fowler, Hughes ve Elias, 2006, s. 1781).

Kompozit yapıların mantığında; bileșenlerin herhangi birinde tek başınayken ulaşılamayan yapısal veya fonksiyonel olanakları, daha kullanışlı bir sistem ile mümkün hale getirmek için farklı sistemlerin birleştirilmesi vardır. Bu amaç doğrultusunda en ilkel kompozit örneği olarak, bina inşası için saman ve çamur karışımından tuğla formu oluşturmak gösterilmektedir (Jose vd., 2012, s. 3-4). Görüldüğü gibi, ilk çağlardan beri kırılgan malzemelerin içine bitkisel veya hayvansal lifler ilave edilerek malzemenin özelliği geliştirilmeye çalışılmıştır. Kerpiç üretiminde killi çamur içine katılan saman ve sarmaşık dalları gibi, sap ve lifler kerpicin mukavemetini artırmaktadır. Bunun yanı sıra, özellikleri ve lif yönleri farklı ağaç levhalar üst üste istiflenerek yapılan ok yayları (Zor, 2018, s. 7-8) ya da kâğıdın kendisi de, kompozit malzemeye gösterilebilecek basit örneklerdendir. Sonuç olarak, kompozit yapılarda iki veya daha fazla sayıda malzemenin bir araya getirilmesiyle; bileşenlerin kendi özelliklerinden daha farklı ve üstün nitelikler kazandırılabileceği gibi, bünyelerinde barındırdıkları iyi özelliklerini bir araya getirmek de mümkün olabilmektedir. Bu yapılar bir karışımdır, ancak bu karışımda bileşenler kimyasal olarak birbirlerini etkilemezler, birbirlerinin içinde bir çözme ve çözünme olayı da gerçekleşmez. 
Uzun ömürleri, hafiflikleri, yüksek kimyasal ve mekanik dayanımları gibi üstün nitelikleri nedeniyle tercih sebebi olan kompozit malzemenin, aynı anda tüm özelliklere ulaşması beklenemez; ancak malzemenin üretiminde hedeflenen amaç ve kullanım alanı doğrultusunda geliştirilebilir (Alpyıldız, 2010, s. 1).

Kompozit materyaller; sürekli faz olarak da adlandırılan matris fazı, matris malzeme ile çevrili olan takviye fazı ve bu fazlardan farklı olan yapıları ve özellikleri ile ara yüzey fazı olmak üzere temelde üç ana fazdan oluşmaktadır (Erdem İşmal ve Paul, 2018, s. 378). Matris, takviye edilen malzemedir ve kompozit malzemenin ana bileşenidir (Ulcay, Akyol ve Gemci, 2002, s. 94). Matrisin kompozit yapı içindeki görevinin; takviye malzemenin etrafını sarmak, onu bağlamak, takviye malzemelerini bir arada tutup yükü takviye malzemesine iletmek, her bir takviye malzemeyi kendi içinde izole etmek ve üretilen kompozitin olabildiğince net şekline yakın bir yüzey kalitesine sahip olmasını sağlamak olduğu söylenebilir. Kompozit bileşenlerinden ikincisi olan takviye malzemelerde, "takviye edici fazın geometrisi, takviye malzemesinin etkisini belirleyen önemli bir parametredir. Başka bir deyişle kompozit malzemenin mekanik özellikleri, takviye edici parçacıkların geometri ve boyutunun bir fonksiyonudur." (Kuzu, 2011, s. 4, 5)

Kompozitleri; matris malzeme, takviye malzeme, lif, reçine ve üretim çeşidine göre sınıflandırmak mümkündür (Erdem İşmal ve Paul, 2018, s. 382-383). Kompozit bir yapıda kullanılan takviye elemanları da kendi içinde ayrıca sınıflandırılarak malzemenin şekline ve yerleştirilme biçimine göre; lifli (kesikli/kesiksiz), parçacıklı (tanecikli), tabakalı ve karma kompozitler olarak adlandırılmaktadır.

\subsection{Malzemeye Yaklaşımda Özgün Karakterde Bir Miras: Tılsımlı Gömlekler}

Tılsımlı Gömlekler, Osmanlı döneminden günümüze kadar gelmiş ve sekiz bin çözgü ipiyle gerçekleşen dokuma tekniğiyle (Güven, 2014, s. 17) yalnızca moda ve tekstilin değil, üzerindeki sembolik unsur ve bezemeleriyle, gök biliminden kitap sanatlarına kadar pek çok araştırmanın konusu olmuş eşsiz birer kültür mirası olarak kabul edilen dönem giysileridir. Bu gömlekler; onu giyen kişiyi kötülüklerden koruması, şifa vermesi ya da savaşta galibiyet kazanması için, üzerine çeşitli yazı, sayı, simge ve sembolik unsurlar uygulanan özel tasarım giysilerdir. Giyilebilen tekstil olmalarına rağmen yüzeyini kâğıt gibi kullanabilmeleri âhar adı verilen bir işlemle, kumaşa kâğıt özelliğinin kazandırılmış olmasıyla mümkün olmuştur. (Tezcan, 2013, s. 679). Yapılan araştırmalarda gömleklerin; hattatların kâğıdı terbiye etmek için kullandıkları özel bir teknik olan âharlama işlemiyle yazıya elverişli hale getirilen ince pamuk kumaşlardan dikilerek, nakkaşlar atölyesinde işlendiği tespit edilmiştir (Güven, 2014, s. 16). Gömlekler için kesilen parçalar, üzerine yazı, motif gibi diğer işlemler yapıldıktan sonra birleştirilmiştir. Kâğıt muamelesi gösterilen bu kumaşlar yüzeyindeki işlevsel mahiyetteki bazı uygulamalarla birlikte, barındırdığı dönemin bezeme anlayışıyla da tezhip sanatına yakınlığıyla da dikkat çeken, işlevsel olduğu kadar görsel estetiğe de sahip tekstillerdir.

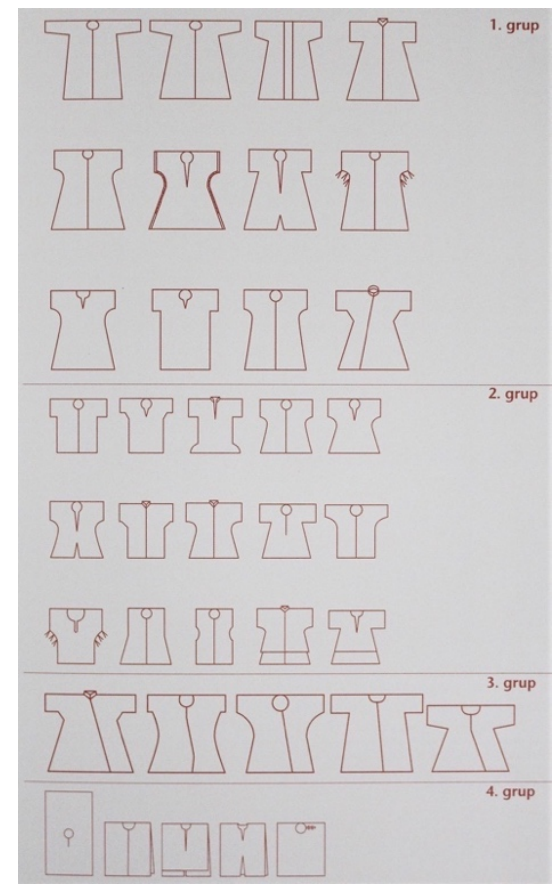

Şekil 2. Tılsımlı Gömleklerin 4 grupta toplanan kesimlerine göre hazırlanmış şematik çizim tablosu (Tezcan, 2011, s. 17). 
Tezyinatı kadar form özellikleriyle de dikkat çekici olan bu gömlekler; Topkapı Sarayı Müzesi'nde Osmanlı tekstili ve padişah giysileri üzerine çalışan Tezcan'ın $(2011$, s. 16) ifadeleriyle, kesimlerine göre dört gruba ayrılmaktadır. Şekil 2'de görüleceği üzere gömleklerin ilk grubunu; kaftan görünümünde, boyu diz altına kadar inen, önü açık, yakasız, kısa ya da uzun kollu olabilen gömlekler oluşturmaktadır. İkinci grup gömlekler kalçalara kadar inen, önü göbeğe kadar ya da tamamen açık, kısa kollu, genellikle yakasız olmakla birlikte nadiren $5 \mathrm{~cm}$ yükseklikte dik yakalı gömleklerdir. Önden çapraz kapanan üçüncü grup ise, ikinci grubun bir çeşididir. Son olarak dördüncü grup da iki yanı açık, bele kadar uzun ve baştan giyilen gömleklerden olușmaktadır.

\section{Materyal ve Yöntem}

\section{1. Çalışmada Kullanılan Aletler, Malzemeler ve Maddeler}

Çalışmada kâğıt kalıbı, dikdörtgen kesitli leğen, hassas terazi, kova, mikser, cam beher, ütü, boncuk iğnesi, nakış iplikleri, nakış makası, kâğıt tela, kurutulmuş çiçekler, atık kâğıtlar, emici bezler, keten kumaşlar, jüt (geri dönüştürülmüş), sentetik ağırlıklı atık lif (geri dönüştürülmüş), poliester (geri dönüştürülmüş), keten, pamuk (geri dönüştürülmüş), sentetik (geri dönüştürülmüş), soya lifi, viskon, tül gibi ince dokulu atık kumaşlar, matris olarak sodyum aljinat, dolgu malzemesi olarak ise pirinç kepeği posası kullanılmıştır.

\subsection{Yöntem}

Daha önce de ifade edildiği üzere kâğıt, yapısı gereği deneysel özgürlük alanı geniş bir malzemedir ve yeni malzemeler; tıpkı bu çalışmaya kâğıt muamelesi gösterilmiş kumaş özelliğiyle esin kaynağı olan Tılsımlı Gömlekler gibi, hemen her alanda kullanıcısı için bir ilham kaynağı olmaktadır. Yukarıda da ifade edildiği gibi, giyilebilir tekstiller olan bu gömleklerin kumaşlarına, kitap ve türevi sanatlarla ilgilenen sanatçıların kullandıkları bir yöntem olan ahârlama işlemi uygulanarak, kumaşın kâğıt yüzeyi gibi kullanılarak yazı ve tezyinata elverişli hale getirilmesi mümkün olmuştur. Bir kültür mirası niteliğindeki bu gömleklerde görülen malzemeye olan alternatif yaklaşım ve farklı bakış açısı, onu özgün kılmış ve yüzeyindeki bezeme ve işlenen konularla astrolojiden modaya pek çok çalışma alanın dikkatini çeken sanat değerinde tekstiller haline getirmiştir. Kendi kültürümüze ait ve birden çok özelliğe aynı anda sahip olan bu gömlekler, çalışmanın konusuna kaynaklık teşkil eden kâğıt özelinde, malzemeye yaklaşım bakımından esin kaynağı olmuştur. Bu sayede yapılan deneysel bazı çalışmalar neticesinde ulaşılan reçeteyle ortaya kâğıt ve tekstil yapılı kompozitler çıkarılmıştır.

İster endüstriyel, ister elde üretim yöntemiyle olsun, kâğıt elde etmek istendiğinde olmazsa olmaz şartlardan biri su, diğeri de selüloz kaynağı olan ağaçlardır. Ancak bu çalışmada kompozit üretimiyle ulaşılmak istenen tekstil tutumlu kâğıt yapılarda, farklı oranlarda olmakla birlikte her ikisinin de ortak paydası olan selüloz ve lif kaynaklarını, atıklar ve geri dönüştürülmüş malzemeler oluşturmaktadır.

Çeşitli kurum ve firmalardan geri dönüştürülmüş tekstil lifleri ve selüloz atıklarından yeniden elde edilmiş kâğıt hamuru temin edilmiştir. Bu malzemeler kullanılarak yapılan deneysel çalışmalar neticesinde optimum değerde bir reçetede karar kılınmıştır. Bu reçeteyle edinilen işlevsel kazanım, artık yalnızca kâğıt olmadığı gibi, tekstil sınıfına da girmeyen yeni bir yaratım malzemesi sunmuştur. Bu sayede yalnızca mürekkep, baskı veya yazı ile sınırlandırılamayacak, duyusal ve deneysel deneyimlere açı tasarımlara olanak sağlayan estetik bir yapı oluşturulmuştur.

Kâğıt Üretimi başlığı altında detaylı olarak açıklandığı üzere, ilk selüloz kaynakları bilinmeyen atık kâğıtlarla tek tip bir reçete oluşturabilme olasılığı düşüktür. Bu nedenle, kâğıt hamuru fabrika fire ve ıskartalarından yeniden üretilmiş hamur sabit tutularak, tek kaynaktan elde edilen selüloz kaynağı ile hazırlanan reçeteden; kesikli (süreksiz) ve kesiksiz (sürekli) lif takviyeli kompozitler elde edilmiştir. Kâğıt ve kompozit malzeme üretim yöntemlerine dair toplanan veriler, bu çalışmada da göz ardı edilmemiş ve yapılan deneysel çalışmalar neticesinde optimum değere ulaşılan reçeteyle, malzemeye müdahale olanakları gözlenerek duyusal ve deneysel kazanımlar sağlanmıştır. Elde edilen tekstil malzemeleri takviyeli kâğıt yapı (kompozit malzeme) reçetesi ise şu şekildedir:

- Kâğıt hamuru: Fabrika fire ve ıskartalarından geri dönüşüm

- Kâğıt hamuru/Banyo miktarı: 100 g kâğıt hamuru için 10 L su (\%1)

- Dolgu maddesi: 20 g pirinç kepeği posası

- Matris malzeme: 10 g sodyum aljinat (suyla karıştırılarak)

- Takviye malzemesine göre kompozit türü: Parçacık ve lif takviyeli sandviç yapılı kompozit

- Lif yerleștirme biçimi: Kesikli ve kesiksiz

- Takviye elemanı: Jüt, (sentetik ağırlıklı) atık lif, poliester, keten, pamuk, viskon, kâğıt ip 
- Kuruma süresi: Oda sıcaklığında 2 gün

- Uygulama: Kâğıt hamuru 1 L su içerisinde bekletilerek lif açılması sağlanmıştır. Tam çözülme sağlanamadığı için lifler, bir karıștırıcı yardımıyla dağıtılmış ve banyo suyunun kalan kısmı da üzerine ilave edilerek \%1 yoğunlukta hamur hazırlanmıștır. Matris olarak kullanılan sodyum aljinat, suya karıştırılarak şişmesi sağlanmış ve pirinç kepeği posası dolgu malzemesi olarak banyo suyuna ilave edilmiştir. Kompozitin ilk tabakası elekten çıkarılmadan, kâğıt iple örülen kafes șeklindeki file ara yüzeye serilmiş ve kompozitteki tutumlarını gözlemek amacıyla farklı özellikteki lifler kafes içlerine yerleştirilmiştir. İkinci tabaka kompozit de hazırlanarak elek üzerindeki kompozitin üzerine yerleştirilmiş ve Şekil 3'te çeşitli liflerden oluşan uygulama örneklerinde görüleceği gibi kuruması sağlanarak, liflerin fiziksel durumları gözlenmiștir.

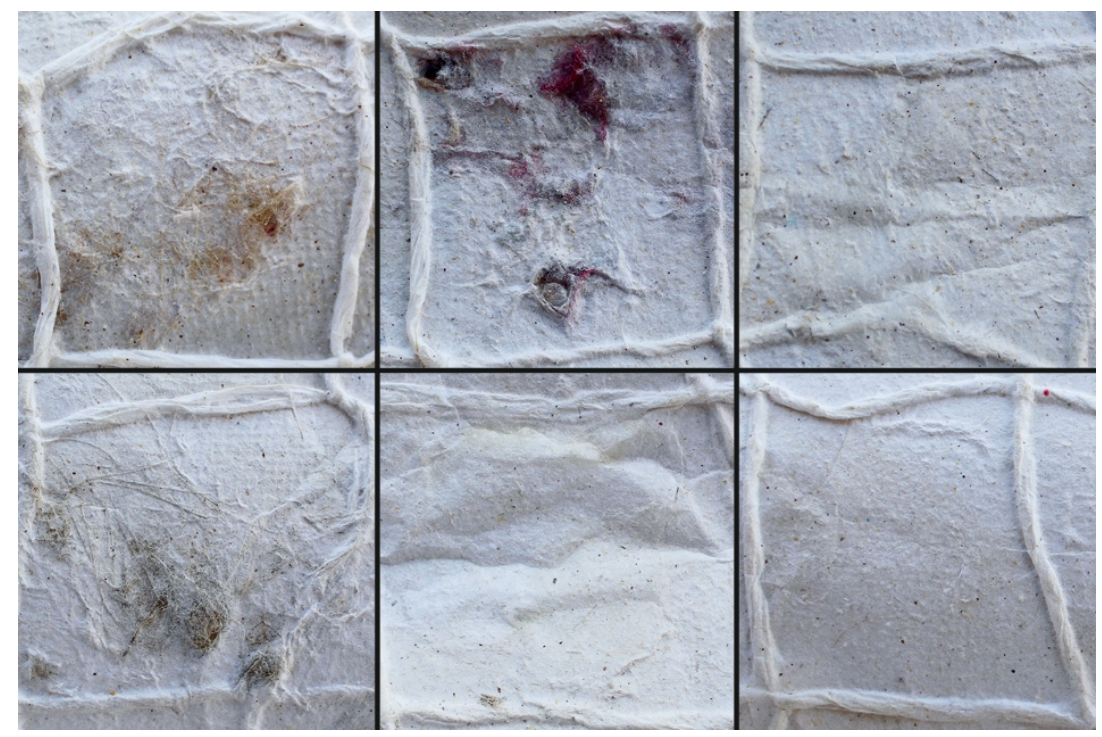

Şekil 3. Soldan sağa üst sıra: Jüt lifi, atık lif ve poliester lifinden oluşan kompozitler. Soldan sağa alt sıra: Keten lifi, pamuk lifi, viskon lifinden oluşan kompozitler.

\section{Sanatsal Uygulama}

Sanatın hemen her dalında olduğu gibi, bu çalışmaya da kültürel bir değer yansımış ve sanatsal uygulamada Tılsımlı Gömleklere yer verilmiştir. Bu gömleklerin kumaş özelliğinin, malzeme bağlamında ilham kaynağı olduğu çalışmada elde edilen kompozitler, Tılsımlı Gömleklerin özelliklerinden biri olan, önden açık, yakalı ve kısa kollu gömlek formunda tasarlanmıştır. Şekil 4'te görüleceği gibi Hazan adı verilen çalışmada, Türk Tezyinî sanatların sembolik anlam ve bezeme aracılığıyla birlikte yaşam döngüsü konu alınmıştır.

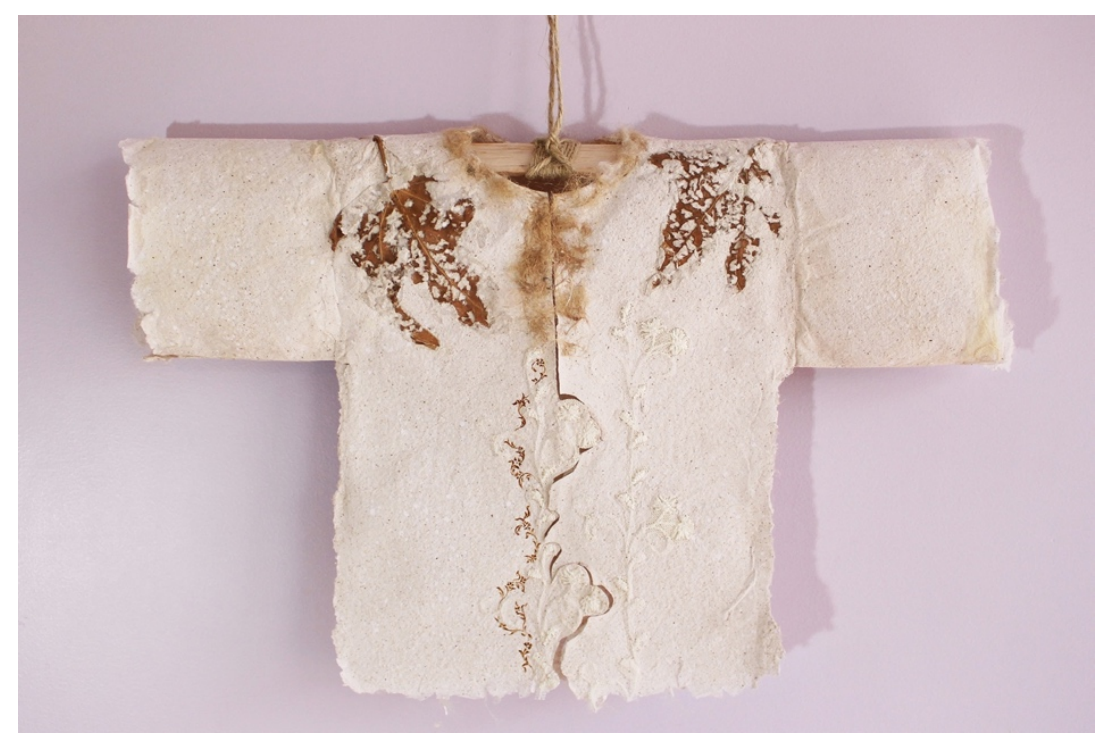

Şekil 4. Hazan, Esra Dereli, 2018 
Çalışmanın tasarım unsuru olarak kullanılan kuru yapraktaki kurt yenikleri, Türk tezyinî sanatlarında sıkça kullanılan bir teknik olan çift tahrir tekniğiyle bağdaştırılmıştır. Şekil 5 'te yenik yaprak örneğinde görülen pozitif-negatif alanlar, Şekil 6'da uygulanan stilize çiçeklerin çift tahrir tekniğinde çalışılma prensibini oluşturmuştur.

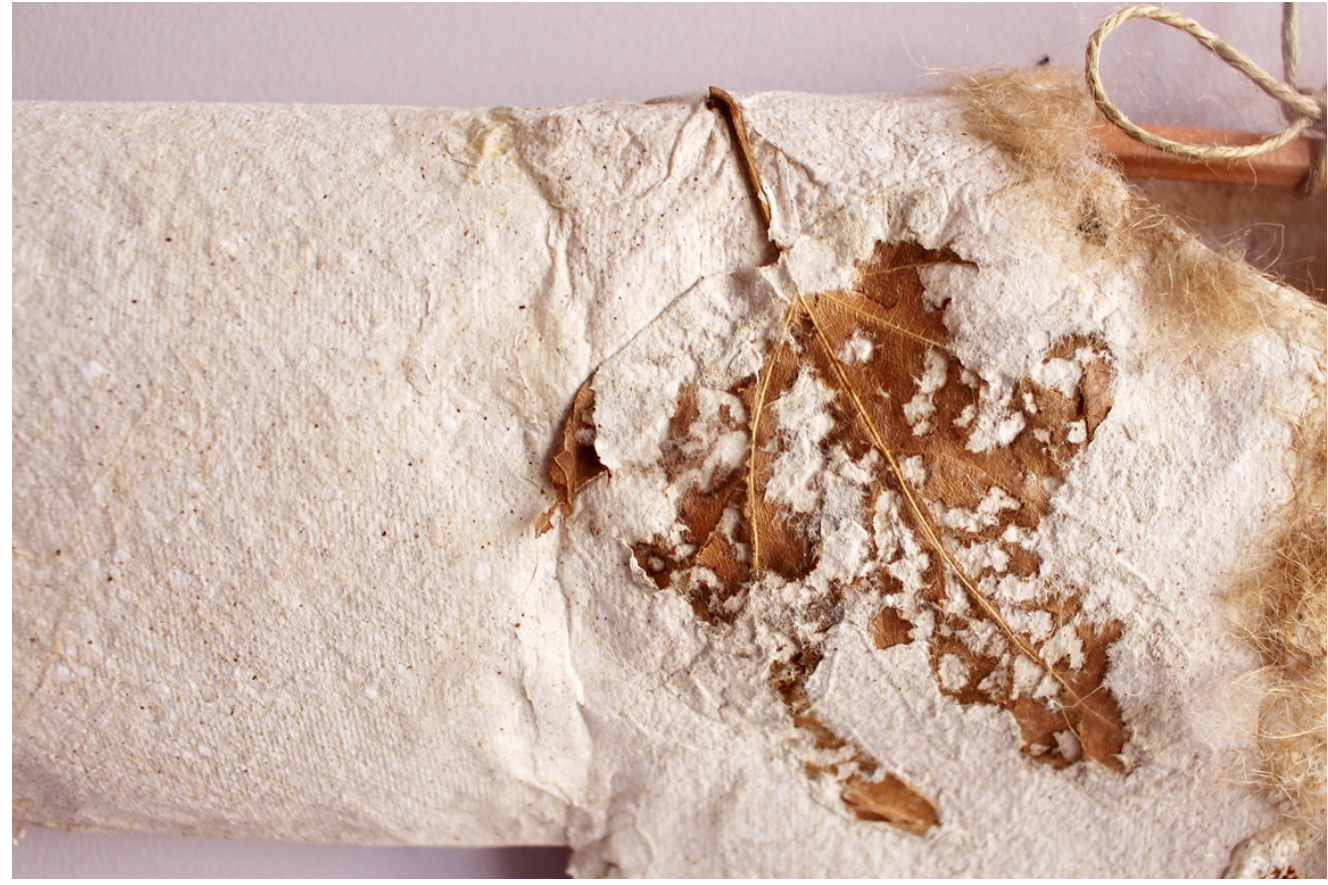

Şekil 5. Kompozit yapının ara yüzeyinde yaprak detayı.

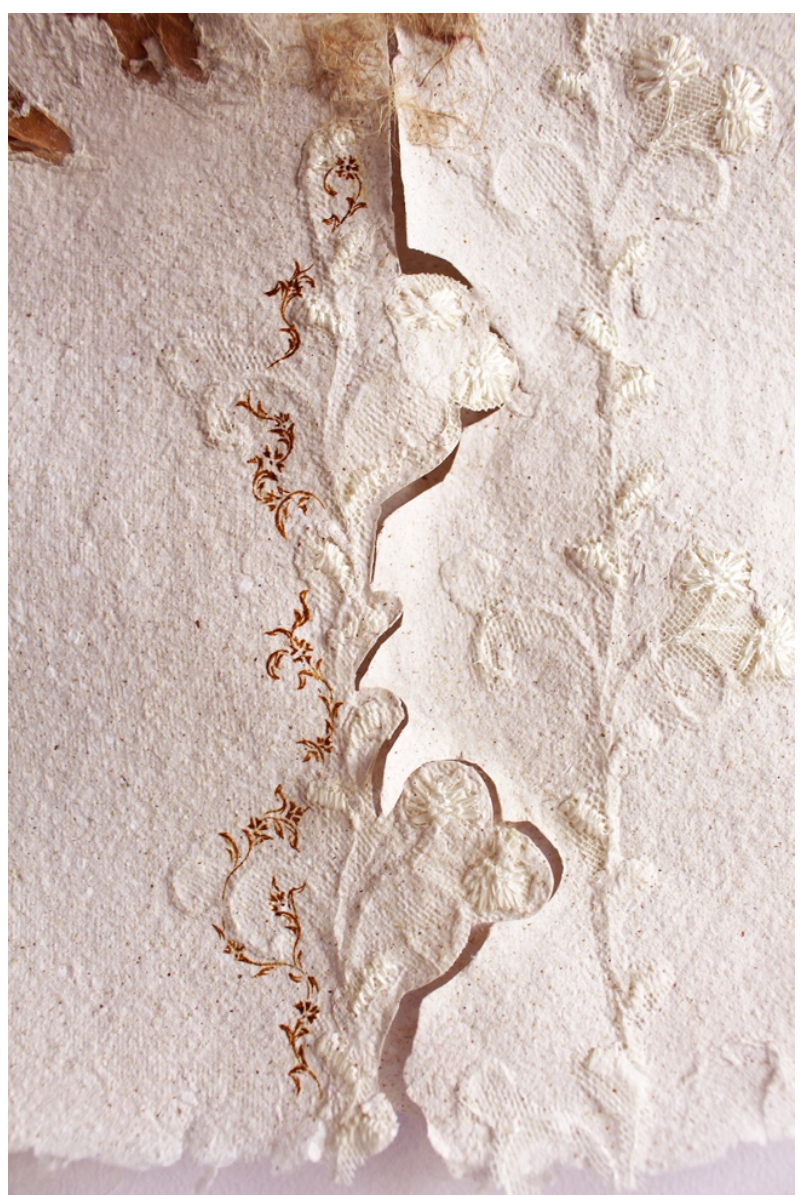

Şekil 6. Çift tahrir tekniği ve doku detayı. 
Kompozitte kullanılan tül kumaşın deseni, tasarımın ön yüzünde serbest bir form oluşturmuştur. Şekil 7'de görüleceği gibi malzemenin oluşturulması esnasında kompozit yüzeye müdahale edilerek, kumaş görünümü alacak șekilde doku oluşturulmuştur. Bu biçimsel dokunuşların yanı sıra Şekil 6'da görülen tülün çiçek dalı deseni renklendirilmeden doku şeklinde bırakılarak, ilkbaharla birlikte yeşerecek olan tohumların, toprak altındaki varlığı vurgulanmıştır.

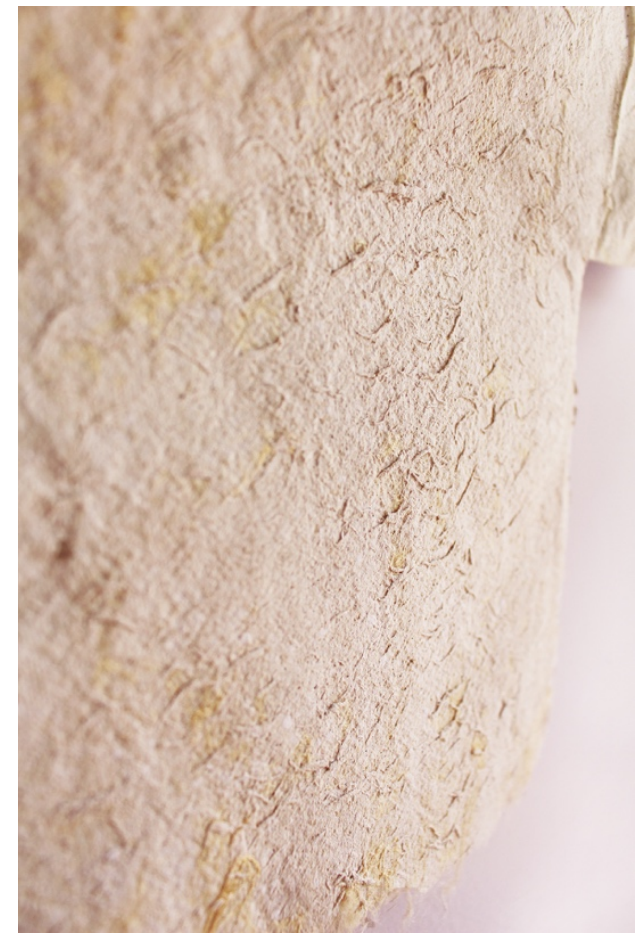

Şekil 7. Kompozit yapıda doku detayı.

Netice olarak; kompozit sınıfına giren tekstil malzemeleri takviyeli kâğıt yapıyla; duyusal ve deneysel bazı müdahale ve aşamalardan sonra kavramsal çerçevedeki söylemi atık ve geridönüşüm malzemeleriyle desteklenen yaşam gözlem ve döngüsünün irdelendiği, Tılsımlı Gömlek formunda tasarlanan sanatsal bir uygulama ortaya konmuştur.

\section{Bulgular ve Tartışma}

Yapılan tespit ve kazanılan edinimler çerçevesinde, atık ve geri dönüşüm kaynaklarından elde edilen kâğıt hamurunun kompozit üretim yöntemiyle buluşmasının, malzeme olarak kâğıdı seçmiş sanatçıların uygulamalarını destekleyici nitelik taşıdı̆̆ı deneyimlenmiştir.

Hazırlanan reçeteyle olușturulan malzemenin üretimi esnasında bazı tespitler yapılmıștır. Bunlardan ilki, atık kâğıtlardaki lif açma sorunu olmuştur. 12 saat suda bekletilen kâğıt hamurunda yeterli lif açılması gözlenmeyince, 5 g sodyum karbonat eklenmiş ancak yine de istenen düzeyde dağılım sağlanamamıştır. Bunun üzerine lifler bir karıștırıcı yardımıyla dağıtılmıștır, fakat hali hazırda hornifikasyona uğramıș liflerin boylarının da kısalmasıyla birlikte, kompozitin dayanıklılığı düşmüş ve liflerin daha fazla zarar görmemesi adına sodyum karbonat kullanım dışına çıkarılmıştır. Dolgu maddesi olarak kullanılan ve yine bir atık olan pirinç kepeği posasından elde edilen kompozitin tutumunun oldukça yumuşak ve ince olduğu görülmüştür. Takviye eleman olarak kullanılan lif çeşidine bağlı olarak kompozitin dayanıklılığı değişkenlik göstermekle birlikte, en yüksek dayanımın keten ve jütte olduğu gözlenmiștir.

Bunların yanında kompozit üretim yöntemi de, çalışmaya bazı olanaklar sağlamış; Şekil 7'deki gibi henüz yaş haldeki kompozit yüzeye müdahale edilerek, hem doku oluşturulabilmiş, hem de ara yüzeyde takviye elyaf olarak kullanılan soya lifleri yer yer yüzeye çıkarılarak kumaş etkisi oluşturmak mümkün hale gelmiştir. Kompozit üretim yöntemi sayesinde oluşan ara yüzey ise, malzemeyi yorumlamayı kolaylaştıran bir unsur olmuştur. Örneğin Şekil 6' da, kompozit ara yüzeyine yerleştirilen tekstil atığı ile yukarıda da ifade edildiği üzere toprak altındaki tohumun varlığına atıf yapılabilmiş ve bu sayede ifade diline olanak 
doğmuştur. Yine Şekil 5'de kullanılan yaprak da, bu üretim şekli sayesinde yukarıda bahsedildiği gibi çift tahrir tekniğiyle bağdaştırılabilmiş ve bir anlam bütünlüğü kurmak mümkün hale gelmiștir.

\section{Sonuç}

Pek çok alanda olduğu gibi sanat ve tasarım alanında da deneysel çalışmalara ilham kaynağının yeni malzemeler olduğu göz önünde bulundurulduğunda, bunun sanata yansıması kaçınılmazdır. Bu arayış içerisinde geleneksel yöntemleri destekleyerek özel üretim metotları sonucunda ortaya çıkan kompozit yapılar, bu çalışma için de tetikleyici unsur niteliğindedir.

Kâğıdın tarihsel süreci, içerisinde bulunduğu çağın koşullarınca ve ihtiyaçlarınca farklılık göstermiş, dolayısıyla günümüze gelindiğinde teknolojinin sağladığı olanaklarla birlikte farklı ihtiyaçlara cevap verecek nitelikte çeşitliliğe ulaşmıştır. Bu çeşitlilik elbette ki boya, baskı ya da mürekkep yoluyla kâğıt yüzeyini kullanacak olan sanatçı için fayda sağlayacaktır. Ancak kâğıdı yorumlamak isteyen sanatçının kâğıt hamuruyla tanışıp, amacına uygun değişikliklerle birlikte hazırlayacağı reçeteyle hareket alanını genişletebileceği bu çalışmada da deneyimlenmiştir. Kâğıdın endüstriyel halinden bağımsız olarak elde üretim gerektirdiği durumlarda, geleneksel yöntemler dışında bu çalışmaya konu edildiğgi șekilde sistematik bir yaklaşıma sahip olmayan halihazırdaki birkaç reçetenin referans alındığı gözlenmiştir. Günümüzde bu tarz disiplinlerarası çalışmaların önem kazandığı ve bunun gerekliliği göz ardı edilmeyerek büyük oranda mühendislik ve kimya bilgisi gerektiren kâğıdın; teknik, sanat ve tasarım iş birlikteliğinde değerlendirilmesinin yapılacak yeni çalıșmalar için farklı bakıș açıları olușturacağı düșünülmektedir. Halihazırda bu vurgu Tılsımlı Gömleklerin kumaş özelliğinde dikkat çekmiş ve malzemeye olan bu yaklaşım, bakış açısını genişleten bir faktör olarak çalışmanın da konusu olmuştur.

Sıklıkla vurgulandığı üzere, yapısı gereği kullanım alanı oldukça geniş bir malzeme olan kâğıt; sanat, hatta tasarım özeline indirgendiğinde de sunduğu olanaklarla duyusal ve deneysel aktarımların temel taşıyıcısı rolünü üstlenmektedir. Geleneksel yöntemlerle başlayan elde kâğıt yapımı; alternatif üretim yöntemleri, kullanılan malzemenin sağladığı olanakların farkındalığı ve edinilen deneyimlerle birleștiğinde, daha özgür ve özgün dilde bir sanatsal söylem ortaya koyulabilmektedir. Amaç her ne kadar sanatsal bir malzeme üretmek olmasa da; söylemini sanat yoluyla gerçekleştirmeyi tercih eden kişinin, aracı olarak kullanacağı malzemeye olan tanışıklığı, aktaracak olduğu söylem için kullandığı dili daha özgün kılabilecek bir unsur olarak görülmektedir.

Kâğıt özelinde birçok alt başlık açan bu çalışmada; malzeme olarak seçilen kâğıt, tekstil lifleri ve kompozit üretim yöntemleriyle Tılsımlı Gömlek formunda bulușturulmuş ve bu sayede atık ve geridönüștürülmüș kaynaklardan elde edilen malzeme biçimlendirilerek sanatsal yaratıma dönüştürülmüştür.

\section{Teşekkür}

Disiplinlerarası bir çalışma olan yüksek lisans tezinden üretilen bu makalede, çalışmaya kâğıt hamuru desteğiyle katkıda bulunan Alkim Kâğıt Sanayi ve Ticaret A.Ş. Genel Müdür Yardımcısı Hasan Mert Uygun’a, tekstil malzemeleri desteğiyle Ege Üniversitesi Mühendislik Fakültesi Tekstil Mühendisliği Bölümü öğretim üyeleri Doç. Dr. Deniz Duran ve Dr. Burcu Karaca Uğural'a teşekkür ederiz.

\section{Kaynakça}

Alpyıldız, T. (2010). Tekstil kompozitleri üzerine bazı çalışmalar (Yayınlanmamış doktora tezi). Dokuz Eylül Üniversitesi Fen Bilimleri Enstitüsü, İzmir.

Bozkurt, C. (2012). Atık kâğıt geri dönüşüm liflerinden üretilen kâğıtların özelliklerinin araştırılması (Yayınlanmamış yüksek lisans tezi). Süleyman Demirel Üniversitesi Fen Bilimleri Enstitüsü, Isparta.

Erdem İșmal, Ö. ve Paul, R. (2018). Composite textiles in high-performance apparel. In McLoughlin, J. ve Sabir, T. (Ed.), High-performance apparel: materials, development and applications (p. 377-20), Elsevier: Woodhead Publishing.

Erentürk, Ș. (2014). Birincil liflere atık kâğıt lifi ve kuru sağlamlık maddesi ilavesinin kâğıdın özelliklerine etkisi (Yayınlanmamış yüksek lisans tezi). Bartın Üniversitesi Fen Bilimleri Enstitüsü, Bartın.

Fowler, P., Hughes, J. ve Elias, R. (2006). Review biocomposites: technology, environmental, credentials and market forces. SCI Food Agric, 86(7), 1781-89. 
Güven, İ. (2014). Osmanlı sultanlarının dua kalkanları. ISSMEK El Sanatları Dergisi, (17), 16-22.

Güven, İ.M.V.N., Kaplanoğlu, L. ve Yangöz, H. (2012). Kâğıt yüzeyine uygulanan sanat eserlerinde kâğıdın önemi. Akdeniz Sanat Dergisi, 5(9), 46-59.

Heideger, M. (2007). Sanat eserinin kökeni (F. Tepebaşılı, Çev.). Ankara: De ki Yayınları.

Jose, J., Malhotra, S., Thomas, S., Joseph, K., Goda, K. ve Sreekala, M. (2012). Advances in polymer composites: macro and microcomposites - state of the art, new challenges and opportunities. In Thomas, S., Joseph, K., Malhotra, S., Goda, K., Sreekala, M. (Ed.), Polymer Composites (p.1-16), New Jersey: John Wiley \& Sons.

Karahan, S. (2008). Ön modifikasyon işlemiyle kâğıt iç yapış̦tırma işleminin iyileștirilmesi (Yayınlanmamış yüksek lisans tezi). Kahramanmaraş Sütçü İmam Üniversitesi Fen Bilimleri Enstitüsü, Kahramanmaraş.

Kömbeci, K. (2014). Domates saplarından lif üretimi (Yayınlanmamış yüksek lisans tezi). Süleyman Demirel Üniversitesi Fen Bilimleri Enstitüsü, Isparta.

Kuzu, A. T. (2011). Tekstil takviyeli polimer matrisli kompozitlerin işlenebilirliğinin incelenmesi (Yayınlanmamış yüksek lisans tezi). İstanbul Teknik Üniversitesi Fen Bilimleri Enstitüsü, İstanbul.

Selimbeyoğlu, C. (2001). Geri dönüşümlü kâğıtlar üzerine renkli baskılarda densitometrik parametrelerin belirlenmesi (Yayınlanmamış doktora tezi). Marmara Üniversitesi Fen Bilimleri Enstitüsü, İstanbul.

Tezcan, H. (2011). Topkapı Sarayı müzesi koleksiyonundan tılsımlı gömlekler. İstanbul: Timaş Yayınları.

. (2013). Dolmabahçe Sarayı'ndaki Sultan II. Abdülhamid'e ait tılsımlı gömlek. Akıncı, N. F. (Ed.), Uluslararası İstanbul Tarihi Yarımada Sempozyumu 2013 içinde (s. 679-90), İstanbul: İSTYAM.

Ulcay, Y. Akyol ve M. Gemci, R. (2002). Polimer esaslı lif takviyeli kompozit malzemelerin arabirim mukavemeti üzerine farklı kür metotlarının etkisinin incelenmesi. Uludağ Üniversitesi MühendislikMimarlık Fakültesi, 7(1), 93-116.

Varlıbaş, H. (2010). Lif modifikasyon işleminin retansiyon üzerine etkileri (Yayınlanmamış yüksek lisans tezi). Kahramanmaraş Sütçü İmam Üniversitesi Fen Bilimleri Enstitüsü, Kahramanmaraş.

Yakut, A. (2012). Geri dönüștürülebilir kullanılmış kâğıttan yeni kâğıt üretiminin irdelenmesi. Tesisat Mühendisliği, 127, 68-75.

Yalçın, B. (2017, 10 Şubat). Dört büyük icat -1- Kâğıdın icadı. Bilimdili. Erişim adresi: https://bilimdili.com/arkeotarih/tarih-tarih/dort-buyuk-icat-1-kagidin-icadi/

Zor, M. (2018, 10 Ocak). Kompozit malzemelerle ilgili genel bilgiler [PDF belgesi]. Erişim adresi: http://kisi.deu.edu.tr/mehmet.zor/composite\%20materials/2-Genel_bilgiler.pdf 